\title{
Pengembangan Perangkat Pembelajaran Fisika dengan Pendekatan Neuroscience untuk Meningkatkan Pemahaman Konsep Siswa SMA
}

\author{
Asriyadin $^{1, a, *}$, Muliana ${ }^{2, b}$ \\ ${ }^{1}$ STKIP Taman Siswa Bima \\ ${ }^{2}$ SMAN 3 Donggo \\ aasriyadin@gmail.com, ${ }^{b}$ siddikmuliana@ymail.com \\ ${ }^{*}$ Corresponding Author
}

\section{Artikel Info}

Tanggal Publikasi

2019-06-30

$\underline{\text { Kata Kunci }}$

neuroscience

pemahaman konsep

\begin{abstract}
Abstrak
Tujuan penelitian ini adalah untuk menghasilkan perangkat pembelajaran fisika menggunakan pendekatan neuroscience bagi siswa SMA. perangkat pembelajaran yang di maksud berupa RPP, LKS, intrumen penilaian pemahaman konsep siswa dan alat peraga fisika berbasis pendekatan neuroscience. Perangkat pembelajaran yang digunakan memenuhi kriteria valid dan efektif. Jenis penelitian ini adalah penelitian pengembangan dengan menggunakan model ADDIE (Analysis, Design, Development, Implementation, Evaluation). Hasil yang dicapai dalam penelitian ini adalah meningkatnya pemahaman konsep fisika siswa setelah menggunakan perangkat pembelajaran dengan pendekatan neuroscience. Selain itu melalui perangkat pembelajaran ini, siswa menjadi terbiasa berpikir secara baik dengan memanfaatkan cara berpikir otak sesuai dengan prinsip pendekatan neuroscience sehingga mampu memahami dengan baik konsep-konsep fisika yang diajarkan. Dari penelitian ini diperoleh peningkatan rata-rata kemampuan pemahaman konsep fisika siswa dari 56,30 menjadi 88,50. Dengan demikian menggunakan perangkat pembelajaran dengan pendekatan neuroscience dapat meningkatkan kemampuan pemahaman konsep fisika siswa.
\end{abstract}

\section{PENDAHULUAN}

Fisika merupakan mata pelajaran yang sangat penting dan memiliki banyak manfaat untuk aplikasi keilmuannya dalam kehidupan sehari-hari. Namun pada kenyataannya banyak siswa yang merasa kesulitan dan tidak memahami secara utuh materi fisika yang disampaikan oleh guru di kelas dikarenakan pelaksanaan pembelajaran yang kurang dikemas dengan sebaik mungkin. Hal ini terlihat jelas pada sekolah menengah atas, dimana siswa masih kesulitan mengingat dan memahami materi ajar fisika (Yusuf, 2015) karena masih dominan pada kegiatan mendengarkan guru, mencatat, dan latihan soal yang bersifat hitungan sehingga cenderung membosankan. Hal ini mengakibatkan siswa jarang memiliki kesempatan untuk melakukan kegiatan eksplorasi yang dapat memotivasi kegiatan belajarnya (Rusman, 2014). Pengetahuan mengembangkan perangkat pembelajaran yang inovatif bagi guru juga masih rendah sehingga banyak guru merasa kesulitan mengembangkan dan memodifikasi perangkat pembelajaran yang sesuai dengan kondisi kelas (Prastowo, 2011).

Fakta di lapangan menunjukkan bahwa tingkat penguasaan konsep fisika di kalangan para siswa SMU di Negara kita masih sangat rendah. Kecenderungan ini juga terjadi di kalangan para siswa tingkat SMU di luar negeri. Untuk mengatasi persoalan ini nampaknya perlu dilakukan perubahan dalam pendekatan pembelajaran fisika. Pendekatan pembelajaran tradisional yang berfokus pada guru sudah tidak cocok lagi digunakan dalam pembelajaran yang mengutamakan penanaman konsep. Akhir-akhir ini berbagai inovasi dalam pendekatan pembelajaran fisika telah banyak dikembangkan dan kemungkinan penerapannya telah dikaji melalui serangkaian penelitian eksperimen. Hasilnya cukup memberi harapan, dari proses penelitian nampak bahwa penggunaan pendekatan-pendekatan baru tersebut dapat lebih meningkatkan pemahaman konsepkonsep fisika dibanding dengan 
pendekatan tradisional. Berbagai pendekatan baru yang dikembangkan tersebut antara lain : Concept First- A Small Group Aproach to Physics Teaching (R. Gautreau and L. Novemsky, 1997), Promoting Conceptual Change Using Collaborative Group in Quantitative Gateway Courses (Calvin. S. Kalman et. al., 1999), Using Interactive Lecture Demonstrations to Create an Active Learning Environment (D.R. Sokoloff and R. K. Thornton, 1997), Interactive Conceptual instruction (Antti Savinainen and Philip Scott, 2001), dan Peer Instruction (E. Mazur, 1997).

Sebagai bagian dari komunitas yang berkecimpung dalam bidang pengajaran fisika, sudah sepatutnya penulis turut ambil bagian memberikan andil dalam pengembangan pembelajaran fisika. Untuk itu melalui program inovasi pembelajaran ini, telah dijajagi pengembangan suatu pendekatan pembelajaran fisika yang merupakan irisan atau perpaduan dari berbagai pendekatan pembelajaran yang telah dikembangkan para ahli di manca negara tersebut. Dengan demikian diharapkan upaya peningkatan pemahaman konsep-konsep fisika dengan menggunakan pendekatan pembelajaran ini dapat memberikan hasil yang lebih optimum. Pendekatan pembelajaran ini dinamakan pendekatan pembelajaran konseptual secara interaktif. Konseptual dimaksudkan pendekatan ini mengutamakan penanaman konsep, sedangkan interaktif dimaksudkan dalam proses belajar mengajar diarahkan untuk terjadi interaksi aktif antara guru dan siswa, maupun antara sesama siswa. Untuk membuktikan bahwa pendekatan pengajaran yang dikembangkan ini benar-benar dapat lebih meningkatkan pemahaman konsep fisika dibanding dengan pendekatan pengajaran tradisional, maka dilakukan penelitian eksperimen untuk ujicoba penggunaannya.

Penggunaan perangkat pembelajaran inovatif dengan pendekatan neuroscience dalam pembelajaran fisika dapat menjadi solusi pada kurangnya pengetahuan terkait desain pembelajaran yang inovatif dan rendahnya pemahaman konsep fisika pada siswa SMA. Pendekatan pembelajaran neuroscience memiliki makna yaitu memanfaatkan kerja otak untuk berpikir secara baik dan optimal dalam memahami sesuatu yang diterima. Dengan pengaplikasian pendekatan neuroscience dalam pembelajaran fisika diharapkan dapat menciptakan kondisi yang lebih kontekstual dan bermakna sehingga siswa lebih tertarik dalam belajar fisika.

Ilmu neuroscience ini telah berkembang cukup lama dan sangat diharapkan dapat diaplikasikan dengan baik pada kurikulum terbaru di SMA. Seiring pesatnya kemajuan teknologi yang menghasilkan metode-metode baru, dapat dilihat bagaimana otak menjalankan fungsi dan kerja mental yang melibatkan pembelajaran dan memori. Berdasarkan hasil penerapan pendekatan neuroscience yang telah dilakukan, didapatkan bahwa neuroscience sangat relevan dengan pembelajaran di kelas dan memberikan implikasi positif bagi pembelajaran, motivasi dan perkembangan pendidikan. Selain itu dipilihnya neuroscience sebagai pedoman pengembangan perangkat pembelajaran menyatakan bahwa pengetahuan, perasaan dan tindakan rata-rata kaintannya dengan kinerja otak, karena pada dasarnya proses kognitif yang meliputi pikiran, keyakinan dan emosi semuanya memiliki representasi yang terkait dengan saraf. Beberapa teknik dalam pembelajaran berbasis kearifan lokal yang dipadukan dengan pendekatan neuroscience dapat diintegrasikan dalam perangkat pembelajaran untuk melatih siswa dalam mengingat pembelajaran dalam waktu yang lama dan membuat suasana belajar menjadi lebih menarik dan komprehensif.

Ciri utama pertama dari pendekatan ini adalah pembelajaran difokuskan pada peningkatan penguasaan konsep. Strategi pembelajaran yang akan digunakan dalam pendekatan ini adalah prinsip "Concept First" yang dikembangkan oleh A. Van Heuvelen. Dengan prinsip ini penanaman konsep fisika dilakukan terlebih dahulu melalui studi kasus dengan tanpa melibatkan konsep matematika. Baru setelah konsep tersebut difahami dengan baik, konsep matematika dilibatkan dalam pembahasan (R. Gautreau \& L. Novemsky, 1997). Dengan cara demikian maka diaharapkan konsepkonsep fisika yang tertanam merupakan konsep-konsep yang benar dan utuh. Disamping itu konsep- 
konsep tersebut dapat tertanam pada diri para siswa secara lebih permanen, sehingga tidak akan cepat hilang ditelan massa.

Pendekatan pembelajar konseptual secara interaktif yang dikembangkan dalam penelitian ini, memiliki ciri-ciri utama yang hampir sama dengan pendekatan pembelajaran yang dikembangkan oleh R. R. Hake (1998), yaitu the interactive-engagement method, dan pendekatan pembelajaran yang dikembangkan oleh Antti Savinainen (2001), yaitu Interactive Conceptual instruction.

Salah satu ciri utama dari keberhasilan pengajaran sains adalah dapat meminimalisasi terjadinya miskonsepsi dikalangan siswa. Konsepsi fisika seorang siswa biasanya tidak terlalu persis sama dengan konsepsi Fisikawan, karena pada umumnya konsepsi Fisikawan akan lebih canggih, lebih kompleks, lebih rumit, dan lebih banyak melibatkan hubungan antar konsep. Jika konsepsi siswa sama dengan konsepsi Fisikawan yang disederhanakan, maka konsepsi siswa tersebut tidak dapat dikatakan salah. Tetapi kalau konsepsi siswa sungguh-sungguh tidak sesuai dengan konsepsi para Fisikawan, maka siswa tersebut dikatakan mengalami miskonsepsi (misconception) (Van den Berg, 1991:10). David Hammer (1996 : 1318) mendefinisikan miskonsepsi sebagai "strongly held cognitive structures that are different from the accepted understanding in a field and that are presumed to interfere with the acquisition of new knowledge".

Salah satu metode yang dapat digunakan untuk mengidentifikasi terjadinya miskonsepsi adalah CRI yang dikembangkan oleh S. Hasan, et. al. (1999 : 296). Keunggulan dari metode ini adalah dalam hal kemudahan dan kecepatan proses identifikasi dan penganalisisan hasilnya. Hal yang paling menarik dari metode ini adalah dapat membedakan antara siswa yang mengalami miskonsepsi dan yang tidak tahu konsep (Kurniawan, 2014)

Penelitian pengembangan ini memiliki tujuan khusus yaitu untuk meningkatkan pemahaman konsep fisika siswa dengan mengembangkan perangkat pembelajaran fisika dalam bentuk Rencana Pelaksanaan Pembelajaran (RPP), Lembar Kegiatan Siswa (LKS), instrument penilaian pemahaman konsep dan alat peraga menggunakan pendekatan neuroscience pada siswa SMA. Penelitian ini perlu dilaksanakan untuk meningkatkan pemahaman konsep fisika di kelas yang sangat penting bagi siswa SMA.

Penelitian ini juga penting dilaksanakan sebagai tahap awal dalam rangka keterlibatan pengembangan kualitas pembelajaran fisika dan mendukung upaya kerjasama yang baik dibidang pendidikan antara universitas dan sekolah. Hasil penelitian ini juga akan berfungsi baik terutama di daerah kota dan kabupaten Bima. Jika penelitian ini terlaksana dengan hasil yang memuaskan, maka perangkat pembelajaran fisika menggunakan pendekatan neuroscience ini dapat disosialisakan kepada rekan dosen,guru-guru IPA/fisika, untuk diintegrasikan dalam kegiatan pembelajaran yang mereka lakukan.

\section{METODE}

Penelitian ini dilaksanakan di SMAN 3 Donggo di kelas XI MIA untuk yang berjumlah 20 siswa. Setelah perangkat pembelajaran disusun, dikembangkan dan divalidasi, selanjutnya perangkat pembelajaran tersebut diuji coba dan diterapkan ke siswa SMA XI MIA. Hasil dari uji coba dan penerapan perangkat pembelajaran selanjutnya dianalisis dan ditarik kesimpulan kaitannya dengan keefektifan perangkat pembelajaran fisika dengan pendekatan neuroscience terhadap kemampuan pemahaman konsep siswa.

Penelitian ini merupakan penelitian pengembangan dimana yang menjadi fokus pengembangan adalah perangkat pembelajaran fisika dengan pendekatan neuroscience yang didesain sedemikian rupa sehingga siswa diarahkan untuk mengembangkan kemampuan pemahaman konsep secara baik. Model penelitian pengembangan yang digunakan dalam penelitian ini adalah model pengembangan 
ADDIE (Analisys, Design, Development, Implementation and Evaluation). Model penelitian ini dianggap cocok dan sesuai dengan karakteristik pengembangan perangkat pembelajaran dan bahan manipulative lainnya (Muruganantham, 2015).

Pengembangan perangkat perangkat dengan pendekatan neuroscience dilaksanakan melalui beberapa tahapan. Tahapan yang harus yang dimaksud yaitu: (1) Tahap Analisis (Analysis). Sebelum melaksanakan pengembangan perangkat pembelajaran, langkah pertama yang dilakukan melakukan analisis. Tahap analisis sudah dilakukan oleh peneliti sebagai bagian dari pengamatan awal sebelum pelaksanaan penelitian. Adapun analisis yang dimaksud adalah analisis kurikulum fisika SMA dan analisis kebutuhan siswa SMA XI MIA untuk mengetahui perkembangan kognitif mahasiswa dalam memahami konsep fisika, perangkat pembelajaran yang digunakan siswa, dan pendekatan pembelajaran yang diterapkan pada siswa. (2) Tahap Desain (Design). Adapaun hal-hal yang dilakukan pada tahap desain yaitu membuat peta kebutuhan perangkat pembelajaran, menentukan struktur perangkat pembelajaran, menyusun instrument penelitian, dan validasi instrument penelitian oleh validator. (3) Tahap Pengembangan (Development). Hal-hal yang dilakukan pada tahap pengembangan yaitu pembuatan alur belajar hypothetics Learning Trajectory (HLT), penulisan perangkat pembelajaran, dan validasi perangkat pembelajaran oleh ahli materi dan ahli media. (4) Tahap Implementasi ( Implementation) Tahap ini merupakan langkah untu mengujicobakan perangkat pembelajaran yang telah dikembangkan. Perangkat pembelajaran dengan pendekatan neuroscience diujicobakan pada siswa SMA kelas XI MIA (5) Tahap Evaluasi (Evaluation). Pada tahap evaluasi merupakan tahap penilaian terhadap perangkat pembelajaran dilihat dari komponen kelayakan isi, penyajian, bahasa, untuk mengetahui kualitas perangkat pembelajaran yang digunakan. Selain itu pada tahap ini juga dilakukan penilaian terhadap efektifitas perangkat pembelajaran dalam memfasilitasi kemampuan pemahaman konsep fisika siswa SMA.

\section{HASIL DAN PEMBAHASAN}

Penggunaan pengembangan perangkat pembelajaran ini meliputi lima tahapan yang dikenal dengan ADDIE yaitu: (1) analysis, (2) design, (3) development, (4) implementation, dan (5) evaluation. Sebelum memulai pengembangan bahan ajar, langkah pertama yang dilakukan adalah melakukan analisis permasalahan dan analisis solusi yang disesuaikan dengan kebutuhan siswa. Analisis permasalah siswa dilakukan melalui observasi penelitian. Observasi dilakukan pada siswa SMA kelas XI MIA semester genap. Dari hasil observasi terdapat beberapa masalah-masalah yang dihadapi oleh siswa yaitu : (1) siswa belum mampu memahami maksud dan tujuan dari soal fisika yang diberikan oleh guru, (2) karena tidak memahami soal-soal tersebut maha siswa tidak mampu menganalisis dan memahami konsep-konsep fisika dan tidak dapat menyimpulkan apakah pekerjaan yang sudah dikerjakan sudah selesai atau belum. Berdasarkan analisis masalah tersebut maka masalah yang dihadapi oleh siswa di kelas tersebut adalah siswa teridentifikasi mengalami kesulitan dalam memahami konsep fisika oleh karenanya membiasakan siswa untuk memanfaatkan kerja otak secara baik dan optimal dengan pendekatan neuroscience adalah solusi dan langkah tepat dengan menggunakan perangkat pembelajaran inovatif.

Pada tahap desain, hal-hal yang dilakukan berdasarkan hasil atau temuan yang diperoleh pada tahap analisis. Hasil dan temuan yang diperoleh dijadikan dasar untuk mendesain perangkat pembelajaran yang dalam hal ini adalah LKS, alat peraga dan instrument penilaian pemahaman konsep. Adapun hal-hal yang dilakukan diantaranya memetakan kebutuhan perangkat pembelajaran, konten perangkat pembelajaran, menentukan struktur perangkat pembelajaran, menyusun instrumen penilaian, instrument peneitian, dan validasi instrumen penelitian oleh dosen ahli. Dari hasil tersebut, berikut dipaparkan rencana desain perangkat pembelajaran dengan pendekatan neuroscience untuk mata pelajaran fisika. 
Pada tahap pengembangan, peneliti menyusun perangkat pembelajaran dengan pendekatan neuroscience. Adapun fokus pengembangan dalam penelitian ini adalah pengembangan LKS, alat peraga dan instrument penilaian. Materi yang dipilih dalam pengembangan modul ini adalah materi gelombang dan bunyi di semester genap. Sedangkan untuk instrumen penilaian yang dikembangkan adalah soal- soal yang dapat merangsang pemahaman konsep siswa. Adapun aspek-aspek yang diperhatikan oleh peneliti dalam pengembangan perangkat pembelajaran ini adalah: 1) perangkat pembelajaran yang dikembangkan harus mampu memancing siswa untuk mengembangkan kemampuan bernalarnya, 2) perangkat pembelajaran yang dikembangkan harus mampu memancing siswa untuk melakukan analisis dan evaluasi terhadap konsep-konsep fisika yang diberikan, 3). perangkat pembelajaran yang dikembangkan harus mampu merangsang proses berpikir siswa untuk mengkreasikan dan memikirkan alternatif jawaban dari setiap permasalahan yang diberikan. Ketiga aspek tersebut menjadi dasar pengembangan perangkat pembelajaran dengan menggunakan pendekatan neuroscience.

Tabel 1. Hasil Validasi perangkat pembelajaran Fisika dengan pendekatan neuroscience

\begin{tabular}{cccccc}
\hline \multirow{2}{*}{ Aspek } & \multicolumn{2}{c}{ Ahli } & \multirow{2}{*}{ Skor Rata-rata } & \multirow{2}{*}{ Nilai } \\
\cline { 2 - 3 } & Materi & Media & & \\
\hline Kelayakan isi & 75 & 78 & & 76,5 & Baik \\
Kelayakan bahasa & 76 & 80 & & 78 & Baik \\
Kelayakan penyajian & 80 & 79 & 79,5 & Baik \\
\hline Kesimpulan & & 78 & Baik \\
\hline
\end{tabular}

Setelah dikembangkan perangkat pembelajaran harus divalidasi terlebih dahulu untuk melihat kelayakan dari perangkat pembelajaran tersebut. Perangkat pembelajaran harus dinyatakan valid dari para ahli setelah itu baru dapat digunakan selanjutnya untuk penelitian. Berikut rekapan hasil validasi oleh para ahli.

Tabel 2. Rangkuman hasil validasi RPP

\begin{tabular}{clc}
\hline Perangkat & \multicolumn{1}{c}{ Indikator } & Penilaian \\
\hline RPP & 1. Kompetensi Dasar dan Indikator & 4,4 \\
& 2. Tujuan Pembelajaran & 4,2 \\
& 3. Kelengkapan & 5 \\
& 4. Materi pembelajaran & 4,5 \\
& 5.Skenario Pembelajaran & 4,3 \\
& 6. Assesmen & 4 \\
& 7. Bahasa & 4 \\
\hline & Rata-rata & 4,3 \\
\hline
\end{tabular}

Penuntun Praktikum

Aspek-aspek yang diperhatikan dalam menvalidasi penuntun praktikum siswa adalah format, bahasa, isi, dan penutup.

Tabel 3. Rangkuman hasil validasi penuntun praktikum

\begin{tabular}{cllc}
\hline \multicolumn{1}{c}{ Perangkat } & \multicolumn{1}{c}{ Indikator } & Penilaian \\
\hline Penuntun Praktikum & 1. & Format dan komponen & 4,3 \\
& 2. Isi & 4,2 \\
& 3. Bahasa & 4 \\
\hline & \multicolumn{2}{c}{ Rata-rata } & 4,2 \\
\hline
\end{tabular}


Lembar Kegiatan Siswa (LKS)

Aspek-aspek yang diperhatikan dalam menvalidasi LKS adalah format (Sistem penomoran, petunjuk penyelesaian LKS, tata ruang, lay out), isi, dan bahasa

Tabel 4. Rangkuman hasil validasi LKS

\begin{tabular}{|c|c|c|}
\hline & Indikator & Penilaian \\
\hline \multirow[t]{3}{*}{ LKS } & 1. Format & 4,2 \\
\hline & 2. Isi & 4,3 \\
\hline & 3. Bahasa & 4 \\
\hline & Rata-rata & 4,2 \\
\hline
\end{tabular}

Tes Kemampuan Pemahaman Konsep

Aspek-aspek yang diperhatikan dalam menvalidasi tes kemampuan pemahaman konsep adalah isi, pedoman penskoran jawaban, dan bahasa.

Tabel 5. Rangkuman hasil validasi tes kemampuan pemahaman konsep siswa

\begin{tabular}{llc}
\hline \multicolumn{1}{c}{ Perangkat } & \multicolumn{1}{c}{ Indikator } & Penilaian \\
\hline Tes Kemampuan & 1. Isi & 4,3 \\
Pemahaman Konsep & 2. Pedoman penskoran jawaban & 4,2 \\
& 3. Bahasa & 4 \\
\hline & Rata-rata & 4,1 \\
\hline
\end{tabular}

Berdasarkan Tabel data hasil validasi di atas dapat disimpulkan bahwa penggunaan perangkat pembelajaran baik untuk LKS maupun Instrumen penilaian keduanya sama-sama berkategori baik atau sangat layak dan valid yang dinilai dari tiga aspek yaitu kelayakan isi, bahasa maupun penyajian atau tampilan. Dengan hasil tersebut maka perangkat pembelajaran dengan pendekatan neuroscience layak untuk dikembangkan atau digunakan dalam pembelajaran fisika di SMA.

Setelah mengembangkan perangkat pembelajaran dengan pendekatan neuroscience, selanjutnya siswa mengikuti proses pembelajaran dengan menggunakan perangkat pembelajaran dengan pendekatan neuroscience. Selanjutnya, untuk mengukur kemampuan pemahaman konsep siswa, juga digunakan instrument dengan pendekatan neuroscience. Namun untuk melihat adanya peningkatan dan pengaruh penggunaan perangkat pembelajaran dengan pendekatan neuroscience maka akan dianalisis dari data atau nilai yang diperoleh siswa sebelum menggunakan perangkat pembelajaran dengan pendekatan neuroscience dan setelah menggunakan perangkat pembelajaran dengan pendekatan neuroscience. Data kemampuan pemahaman konsep siswa sebelum menggunakan perangkat pembelajaran dengan pendekatan neuroscience.

Tabel 6. Hasil Kemampuan Pemahaman Konsep Fisika Siswa

\begin{tabular}{lcc}
\hline \multicolumn{1}{c}{ Variabel } & Pretest & Posttest \\
\hline Rata-rata & 56,30 & 88,50 \\
N Tuntas & 7 & 16 \\
N di kelas & 20 & 20 \\
Ketuntasan (\%) & 35,00 & 80,00 \\
\hline
\end{tabular}

Berdasarkan Tabel 6 di atas, dapat dijelaskan bahwa sebelum menggunakan perangkat pembelajaran dengan pendekatan neuroscience rata-rata nilai kemampuan pemahaman konsep siswa yang diperoleh adalah 56,30. Setelah menggunakan perangkat pembelajaran dengan pendekatan neuroscience nilai yang diperoleh adalah 88,50 dengan persentase masing-masing 35,00 \% dan 80,00\%. 
Secara umum penelitian ini memiliki beberapa tahapan dimana tahap pertama dimulai dengan melakukan analisis kebutuhan siswa SMAN 3 Donggo kelas XI MIA, dilanjutkan dengan pengembangan, perangkat pembelajaran dengan pendekatan neuroscience dilanjutkan dengan validasi perangkat pembelajaran dengan pendekatan neuroscience, uji coba terbatas, pelaksanaan penelitian dan terakhir analisis data. Penelitian pengembangan ini mendiskripsikan tentang penggunaan perangkat pembelajaran dengan pendekatan neuroscience dapat meningkatkan kemampuan pemahaman konsep siswa. Perangkat pembelajaran dengan pendekatan neuroscience dimaksudkan untuk membiasakan asiswa untuk selalu berpikir tingkat tinggi sehingga dengan kebiasaan tersebut siswa memiliki kemampuan pemahaman konsep fisika yang baik.

Hasil Penelitian menunjukkan bahwa pengembangan perangkat pembelajaran dengan pendekatan neuroscience dapat meningkatkan kemampuan pemahaman konsep fisika siswa. Hal ini sejalan dengan pendapat Maladjuna (2013) yang menyebutkan bahwa dengan memiliki pemahaman yang baik akan mampu belajar (learning), mampu memberikan alasan dengan tepat (reasoning), berpikir kreatif (Creative Thinking), membuat keputusan (making decisions), dan menyeles- aikan masalah (problem solving). Pendapat tersebut menjelaskan bahwa pendekatan neuroscience mampu meningkatkan beberapa kompetensi yang salah satunya adalah kemampuan pemahaman konsep . Teori tersebut sejalan dengan pedapat Riswati (2012) yang menyebut- kan bahwa melalui pendekatan neuroscience peserta didik akan dapat membedakan ide atau gagasan secara jelas, berargumen dengan baik, mampu memecahkan masalah, mampu mengkonstruksi penjelasan, mampu berhipotesis dan memahami hal-hal kompleks menjadi lebih jelas.

Selama pelaksanaan penelitian, penggunaan perangkat pembelajaran dengan pendekatan neuroscience memberikan pengaruh yang signifikan terhadap aktivitas belajar siswa. Pembelajaran menjadi lebih produktif khususnya dalam interaksi sociocognitive, misalnya dalam hal: (1) mengajukan pertanyaan, kerjasama dan diskusi kelompok antar siswa lebih meningkat, rasa ingin tahu yang tinggi, meningkatkannya kemampuan menjelaskan konsep hasil diskusi, menyelesaikan tugas maupun latihan dengan baik, dan siswa semakin senang menyelesaikan soal-soal atau permasalahan yang diberikan. Semua pengaruh positif tersebut berdampak langsung dengan meningkatnya kemampuan pemahaman konsep fisika siswa yang berdampak juga pada hasil belajar siswa.

\section{KESIMPULAN}

Berdasarkan hasil penelitian dan analisis data maka kesimpulan dari penelitian ini adalah pengembangan penggunaan perangkat pembelajaran dengan pendekatan neuroscience dengan prosedur menggunakan prosedur ADDIE (Analysis, Design, Development, Imple-mentation, Evaluation) dapat meningkatkan kemampuan pemahaman konsep fisika siswa. Selain itu diperoleh juga hasil bahwa penggunaan perangkat pembelajaran dengan pendekatan neuroscience dapat meningkatkan pemahaman konsep siswa dengan rata-rata peningkatandari 56,30 menjadi 88,50, (3) dari hasil uji validitas oleh para ahli baik ahli media maupun ahli materi dapat disimpulkan penggunaan perangkat pembelajaran dengan pendekatan neuroscience dinyatakan valid dengan nilai rata-rata 3,5 s/d 4,5 atau dengan kategori baik atau valid. Artinya penggunaan perangkat pembelajaran dengan pendekatan neuroscience layak digunakan untuk meningkatkan kemampuan pemahaman konsep fisika siswa.

\section{Daftar Pustaka}

Gautreau, R., Novemsky, L., (1997), Concept First-A Small Group Approach To Physics Learning, Am. J. Phys. 65 (5) 418-428 
Hake, R. R., (1998), Interactive-Engagement versus Traditional Methods : A Six-Thousand-Student Survey of Mechanics Test Data for Introductory Physics Course, Am. J. Phys. 66(1) 64- 74 Hasan, S., Bagayoko, D., Kelley, E.L., (1999), Misconseptions and the Certainty of Response Index (CRI), Phys. Educ. 34(5), pp. 294 - 299.

Hammer, D., (1996), More Than Misconceptions : Multiple Perspectives on Student Knowledge and Reasoning, and an Appropriate Role for Education Research, Am. J. Phys., 64(10), pp. 1316 1325.

Kalman, C. S., (1999), Promoting Conceptual Change Using Collaborative Groups in Quantitative Gateway Courses, Phys. Educ. Res., Am. J. Phys. Suppl. 67 (7) S45 - S51

Kurniawan, A.D. 2013. Metode inkuiri terbimbing dalam pembuatan media pemeblajaran biologi untuk meningkatkan pemahaman konsep dan kreativitas siswa SMP. Jurnal Pendidikan IPA Indonesia, 2(1):8-11

Maladjuna, D.A., Saehana, S dan Syamsu. 2013. Pengaruh model pembelajaran inkuiri terbimbing terhadap pemahaman konsep siswa pada mata pelajaran fisika di SMP Negeri 19 Palu. Jurnal Pendidikan Fisika, 5(1):7-10

Mazur, E., (1997), Peer Instruction : A User Manual, Englewood Cliffs, NJ : Prentice Hall

Prastowo, A. 2011. Panduan Kreatif mebuat Bahan Ajar Inovatif. Yogyakarta: Diva Press

Rismawati., Ratman, dan Dewi, A.I. 2012. Penerapan metode eksperimen dalam meningkatkan pemahaman konsep energi panas pada siswa kelas IV SDN No 1 Balukang 2. Jurnal Kreatif, 4(1):199-215.

Rusman. 2014. Model-Model Pembelajaran, Mengembangkan Profesionalisme Guru. Jakarta: Rajagrafindo Persada

Savinainen, A., Scott, P., (2001), Using The Force Concept Inventory To Monitor Student Learning and To Plan Teaching, Phys. Educ. 37(1) 53-58

Sokoloff, D. R., Thornton, R. K., (1997), Using Interactive Lecture Demonstrations To Create an Active Learning Environment, The Physics Teacher 35. 340-347

Yusuf, A. M. 2015. Asesmen dan Evaluasi Pendidikan. Jakarta: Prenadamedia Group

Van den Berg, E., (1991), Miskonsepsi Fisika dan Remediasi, UKSW, Salatiga

Van Heuvelen, A., (1996), ALPS Kit (Active Learning Problem Sheets Kit) : Mechanics, HaydenMcNeil Publishing, Inc. 